REVIEW PAPER

\title{
Photovoltaic solar farms in California: can we have renewable electricity and our species, too?
}

\author{
BRIAN L. CYPHER ${ }^{1 *}$, BRIAN B. BOROSKI², ROBERT K. BURTON ${ }^{3}$, \\ DANIEL E. MEADE ${ }^{4}$, SCOTT E. PHILLIPS ${ }^{1}$, PHILIP LEITNER ${ }^{1}$, \\ ERICA C. KELLY ${ }^{1}$, TORY L. WESTALL ${ }^{1}$, AND JASON DART ${ }^{4}$
}

${ }^{1}$ California State University-Stanislaus, Endangered Species Recovery Program, One University Circle, Turlock, CA 95382, USA

${ }^{2}$ H. T. Harvey \& Associates, 8080 N. Palm Avenue, Suite 205, Fresno, CA 93711, USA

${ }^{3}$ California State University-Monterey Bay, Applied Environmental Science, 100 Campus Center, Seaside, CA 93955, USA

${ }^{4}$ Althouse and Meade, Inc., Paso Robles, CA 93446, USA

*Corresponding Author: bcypher@esrp.csustan.edu

Photovoltaic solar power generating facilities are proliferating rapidly in California and elsewhere. While this trend is welcomed for many reasons (e.g., reducing greenhouse gas emissions), these facilities also can have profound environmental impacts, particularly to local species populations. These impacts become more significant when species of conservation concern are affected. In the San Joaquin Desert region in central California, a number of conservation measures have been routinely implemented on solar facilities, and these measures have facilitated continued use of the facilities by a number of species of conservation concern. Some of the more significant measures include permeable security fences, vegetation management, movement corridors, avoiding critical features such as dens and burrows, and vehicle speed limits. Detailed studies have been conducted on San Joaquin kit foxes (Vulpes macrotis mutica) using solar facilities in the San Joaquin Desert. Demographic and ecological attributes of foxes are similar between foxes using the facilities and foxes on nearby reference sites, and values for foxes on solar sites are within the ranges of values for foxes reported from sites within core population areas. Facilitated by the conservation measures, kit foxes are using at least six facilities in the San Joaquin Desert as are a variety of other species of conservation concern. This successful model also potentially could be adapted to other ecosystems and applied to facilities in regions outside of the San Joaquin Desert, such as the Mojave Desert. Determining whether species in other regions can use photovoltaic solar facilities and identi- 
fying the most efficacious conservation measures will require time and testing, and these efforts would benefit from collaborative efforts among landowners, solar developers, natural resources agencies, researchers, and others. The San Joaquin Desert facilities and a recent demonstration facility in the Mojave Desert provide strong evidence that solar facilities can be constructed and operated in a manner that also accommodates continued use of the facilities by some species of conservation concern.

Key words: endangered species, conservation, mitigation strategies, Mojave Desert, San Joaquin Desert, solar farms, species of conservation concern

Photovoltaic solar power energy generation is expanding rapidly worldwide (REN21 2016) and particularly in California (Solar Energy Industries Association 2016). Lands with optimal conditions for the construction of utility-scale photovoltaic solar energy generation facilities (e.g., flat terrain, low-structured vegetation, high insolation rates) are abundant in California (Lovich and Ennen 2011; National Renewable Energy Laboratory 2011; Cameron et al. 2012; Stoms et al. 2013). Further incentive has been provided by bills passed by the California legislature that mandate increasing levels of energy production from renewable energy sources with the latest bill requiring that all power-supplying utilities obtain at least $60 \%$ of their electricity from such sources by 2030 and $100 \%$ by 2045 (de León 2018). As of 2019, 748 solar plants were operating in California with many more planned for construction (California Energy Commission 2020; Kern County Planning Department 2020).

The expansion of solar energy clearly is positive in many regards, particularly the associated reduction in greenhouse gas emissions compared to energy generation using fossil fuels. However, photovoltaic solar energy production can produce detrimental environmental impacts, particularly when the production facilities are constructed on natural lands. These impacts can include habitat loss, habitat fragmentation and disruption of movement corridors, direct and indirect mortality, and alteration of ecosystem processes, among others (Tsoutsos et al. 2005; Lovich and Ennen 2011; Stoms et al. 2013; Hernandez et al. 2014; Moore and Pavlik 2016; Moore-O'Leary et al. 2017). These impacts can be even more significant when species of conservation concern are potentially affected (Leitner 2009; Lovich and Ennen 2011; Moore-O'Leary et al. 2017; Boroski 2019; Phillips and Cypher 2019). We define species of conservation concern as those that are federally or state listed as endangered or threatened and California Species of Special Concern (CDFW 2020). Such species that have been affected by recent photovoltaic solar projects in California include the San Joaquin kit fox (Vulpes macrotis mutica; federal endangered, California threatened), giant kangaroo rat (Dipodomys ingens; federal endangered, California endangered), desert tortoise (Gopherus agassizii; federal threatened, California threatened), blunt-nosed leopard lizard (Gambelia sila; federal endangered, California endangered), Mohave ground squirrel (Xerospermophilus mojavensis; California threatened), San Joaquin antelope squirrel (Ammospermophilus nelsoni; California threatened), and others (Leitner 2009; Moore-O'Leary et al. 2017; Boroski 2019; Phillips and Cypher 2019).

The San Joaquin Desert region (Germano et al. 2011) has been a focal area for photovoltaic solar energy development due to an abundance of mostly flat terrain, high insolation rates, and relatively low land prices (Butterfield et al. 2013; Pearce et al. 2016; Hoffacker et al. 2017; Phillips and Cypher 2019). One of the densest concentrations of rare species in the 
United States also occurs in this region (USFWS 1998; Germano et al. 2011) creating the potential for significant conflict between development and conservation (Phillips and Cypher 2019). Despite this potential, several utility-scale solar plants have been constructed in the region and more are planned (e.g., Kern County Planning Department 2020). However, a number of conservation measures have been incorporated into the design and operation of these facilities, and further conservation and planning efforts are warranted as more utilityscale photovoltaic solar plants are planned (e.g., Kern County Planning Department 2020). As a result of conservation efforts to date, most of the species of conservation concern that were present on or near individual sites prior to construction of the facilities are still present.

Our objectives in this synthesis are to (1) provide examples of species of conservation concern that are using solar facilities in the San Joaquin Desert region, (2) list the conservation measures that are facilitating continued use of the facilities by these species, (3) highlight demographic and ecological data from San Joaquin kit foxes using solar sites, and (4) discuss how the development and implementation of conservation strategies in regions outside of the San Joaquin Desert could benefit a number of other species.

\section{SAN JOAQUIN DESERT SOLAR PROJECTS, SPECIES, AND CONSERVATION MEASURES}

The San Joaquin Desert includes the arid western and southern portions of the San Joaquin Valley, the Carrizo Plain, and some smaller valleys along the eastern edge of the Coast Ranges (Fig. 1). Geographic, climatic, abiotic, and biotic attributes of this region are detailed in Germano et al. (2011). As stated previously, large portions of this region

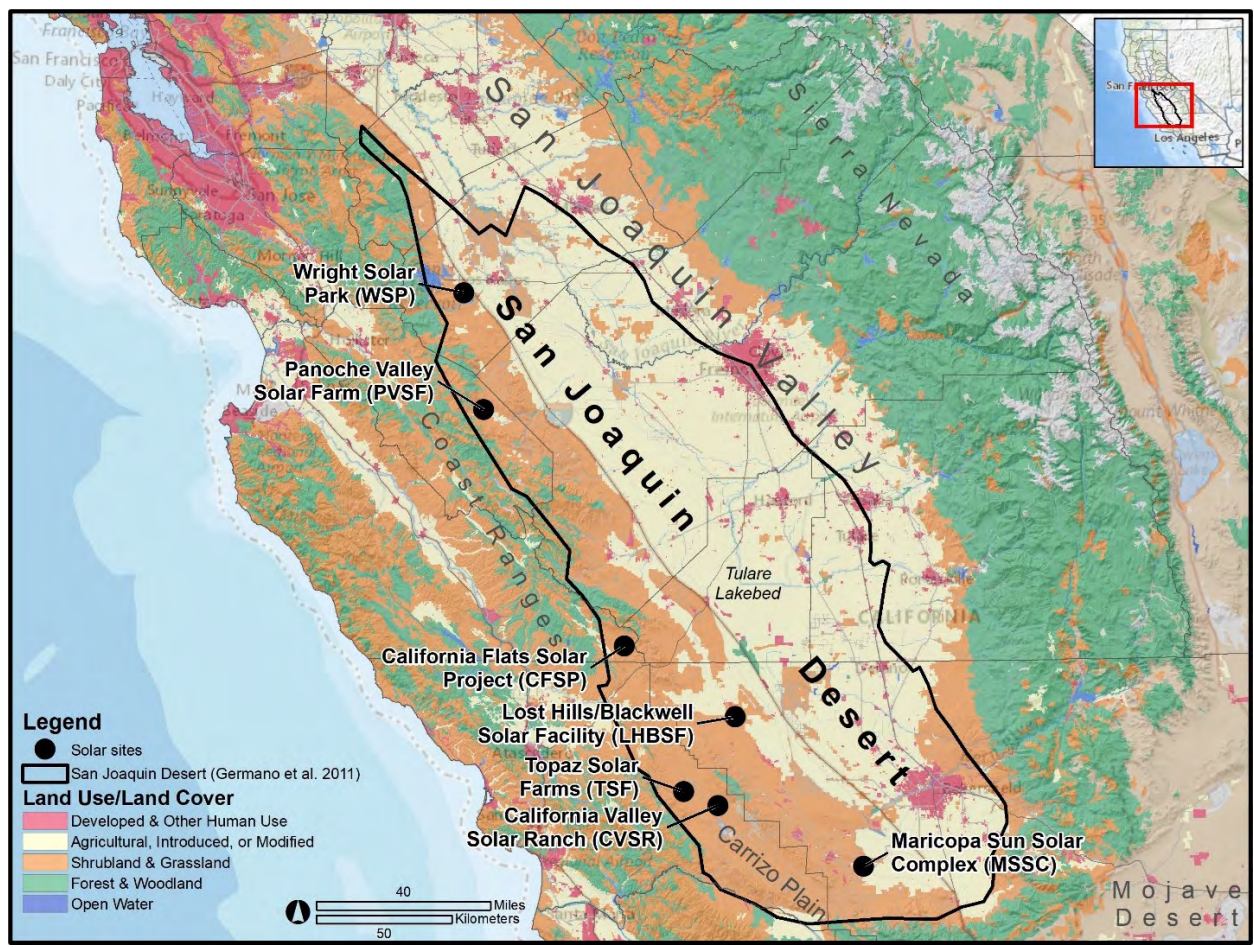

Figure 1. Locations of seven large photovoltaic solar facilities in the San Joaquin Desert of California. 
are highly suitable for solar energy development. Consequently, a number of photovoltaic solar facilities ranging from a few to hundreds of hectares have been constructed and more are planned. All of these facilities employ photovoltaic solar panels to generate electricity. Many of these facilities were constructed on lands that were in agricultural crop production up until just prior to construction. However, at least six facilities were constructed on grazing lands or natural lands that were occupied by one or more species of conservation concern (Fig. 1, Table 1).

Table 1. Species of conservation concern that use seven solar photovoltaic energy generating facilities in the San Joaquin Desert region of California. Status codes are as follows: FE = Federal Endangered; $\mathrm{FT}=$ Federal Threatened; $\mathrm{CE}=$ California Endangered $\mathrm{CT}=$ California Threatened $\mathrm{CSSC}=$ California Species of Special Concern.

\begin{tabular}{|c|c|c|c|c|c|c|c|c|}
\hline \multirow[b]{2}{*}{ Species } & \multicolumn{4}{|c|}{$\begin{array}{l}\text { Solar facilities } \\
\text { (size of the facility) }\end{array}$} & \multirow[b]{2}{*}{$\begin{array}{c}\text { CFSP } \\
\text { (1174 } \\
\text { ha) }\end{array}$} & \multirow[b]{2}{*}{$\begin{array}{l}\text { LHBSF } \\
\text { (125 } \\
\text { ha) }\end{array}$} & \multirow[b]{2}{*}{$\begin{array}{c}\text { WSP } \\
\text { (567 } \\
\text { ha) }\end{array}$} & \multirow[b]{2}{*}{$\begin{array}{c}\text { MSSC } \\
(65 \\
\text { ha) }\end{array}$} \\
\hline & Status & $\begin{array}{l}\text { TSF } \\
(1902 \\
\text { ha) }\end{array}$ & $\begin{array}{l}\text { CVSR } \\
(797 \\
\text { ha) }\end{array}$ & $\begin{array}{l}\text { PVSF } \\
(526 \\
\text { ha) }\end{array}$ & & & & \\
\hline $\begin{array}{l}\text { San Joaquin kit fox } \\
\text { (Vulpes macrotis mutica) }\end{array}$ & $\begin{array}{l}\mathrm{FE} \\
\mathrm{CT}\end{array}$ & $X$ & $X$ & $X$ & $X$ & $X$ & X & \\
\hline $\begin{array}{l}\text { American badger } \\
\text { (Taxidea taxus) }\end{array}$ & CSSC & $X$ & $X$ & $X$ & $X$ & $X$ & $X$ & $X$ \\
\hline $\begin{array}{l}\text { Giant kangaroo rat } \\
\text { (Dipodomys ingens) }\end{array}$ & $\begin{array}{l}\mathrm{FE} \\
\mathrm{CE}\end{array}$ & & $X$ & $X$ & & & & \\
\hline $\begin{array}{l}\text { San Joaquin antelope squirrel } \\
\text { (Ammonspermophilus nelsoni) }\end{array}$ & $\mathrm{CT}$ & & $\mathrm{X}$ & $X$ & & $X$ & & \\
\hline $\begin{array}{l}\text { Swainson's hawk } \\
\text { (Buteo swainsoni) }\end{array}$ & $\mathrm{CT}$ & & & & & & & $X$ \\
\hline $\begin{array}{l}\text { Burrowing owl } \\
\text { (Athene cunicularia) }\end{array}$ & $\mathrm{CSSC}$ & $X$ & $X$ & $X$ & $X$ & $X$ & $X$ & $X$ \\
\hline $\begin{array}{l}\text { Northern harrier } \\
\text { (Circus hudsonius) }\end{array}$ & CSSC & & & & & & & $X$ \\
\hline $\begin{array}{l}\text { Loggerhead shrike } \\
\text { (Lanius ludovicianus) }\end{array}$ & $\mathrm{CSSC}$ & & & & & $X$ & & $X$ \\
\hline $\begin{array}{l}\text { Blunt-nosed leopard lizard } \\
\text { (Gambelia sila) }\end{array}$ & $\begin{array}{l}\mathrm{FE}, \\
\mathrm{CE}\end{array}$ & & & $X$ & & $X$ & & \\
\hline $\begin{array}{l}\text { California tiger salamander } \\
\text { (Ambystoma californiense) }\end{array}$ & $\begin{array}{l}\text { FT, } \\
\text { CT }\end{array}$ & & & $X$ & & & & \\
\hline $\begin{array}{l}\text { San Joaquin coachwhip } \\
\text { (Masticophis flagellum rud- } \\
\text { docki) }\end{array}$ & $\mathrm{CSSC}$ & & & & & $X$ & & \\
\hline $\begin{array}{l}\text { Kern mallow } \\
\text { (Eremalke kernensis) }\end{array}$ & $\mathrm{FE}$ & & & & & & & $X$ \\
\hline
\end{tabular}

${ }^{a}$ Solar facilities: TSF = Topaz Solar Farms; CVSR = California Valley Solar Ranch; PVSF = Panoche Valley Solar Farm; CFSP = California Flats Solar Project; LHBSF = Lost Hills/Blackwell Solar Facility; WSP = Wright Solar Park; MSSC = Maricopa Sun Solar Complex 
Consequently, each of the solar facilities were constructed and are operated with a variety of conservation measures designed to facilitate continued occupation by the species. Some of these measures were proposed by the project proponents, some were developed by the CDFW or USFWS, and all were included as requirements in the Incidental Take Permit issued for each project under the California Endangered Species Act. The measures are numerous, and we do not provide a complete list. Instead, we focus on what we consider to be the more important measures. Two measures in particular are critically important in facilitating use of solar facilities by species of conservation concern: one is permeable security fencing, and another is the encouragement and management of vegetation within the facilities. These measures were designed to accommodate and encourage San Joaquin kit foxes, the largest of the listed species using the facilities. However, the measures also benefit most of the other species listed in Table 1, many of which have habitat requirements overlapping those of kit foxes.

At each of the facilities, the security fence surrounding the arrays of solar panels was designed to be permeable to kit foxes, as well as the smaller species of conservation concern and prey species. The fences are typically $2.4 \mathrm{~m}$ tall, sometimes with strands of barbed wire on the top. At most facilities, the fencing used was 5 -cm mesh chain-link. To make it permeable to kit foxes, a gap of approximately $12-15 \mathrm{~cm}$ was left between the bottom of the fence and the ground (Fig. 2). Kit foxes can easily move through this gap. At the

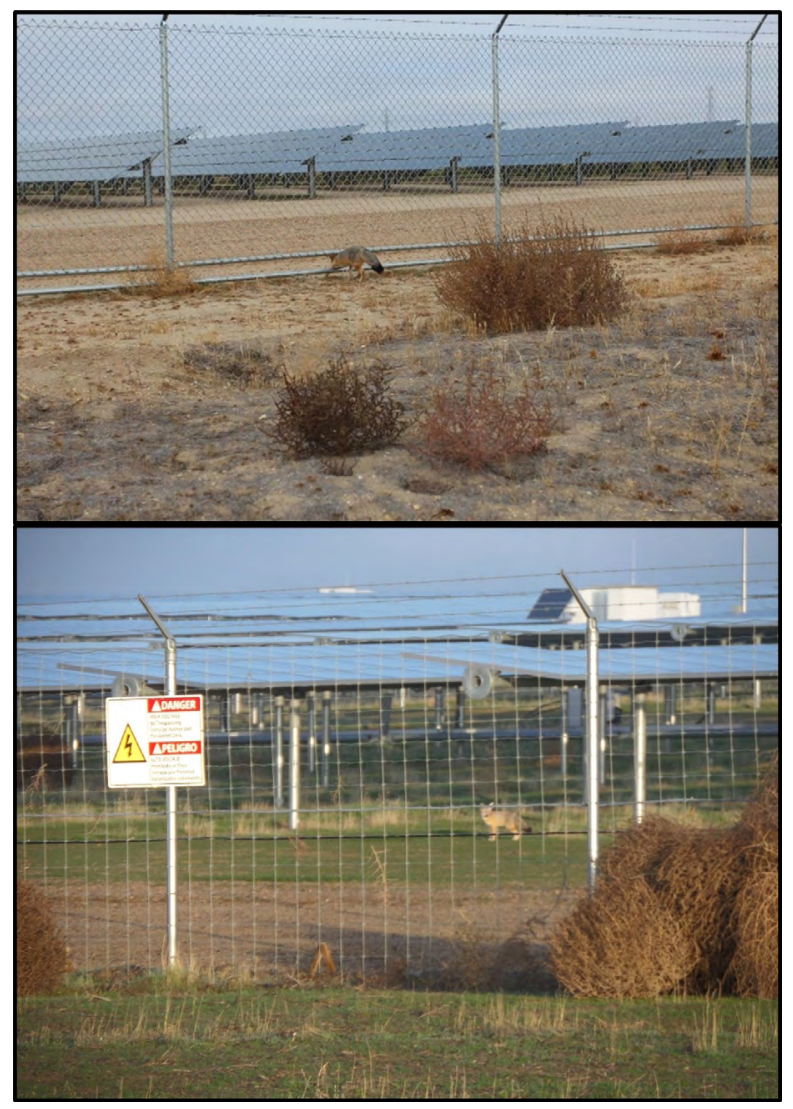

Figure 2. Images of security fences that are permeable to San Joaquin kit foxes at the Topaz Solar Farms (a kit fox is visible crossing through the gap at the bottom of the fence) and California Valley Solar Ranch (a kit fox that just crossed through the fence is visible inside the facility) in San Luis Obispo County, California. (Top photo by Larry Saslaw; bottom photo by Christine Van Horn Job.) 
Topaz Solar Farms (TSF), a rail was installed at the bottom of the gap to discourage larger animals from digging under the fence. At the California Valley Solar Ranch (CVSR) facility, a deer-proof style fence with 15 x 15-cm mesh openings was used (Fig. 2). All of these designs allow kit foxes and any similar sized or smaller species to pass through the fences and freely enter or exit the facilities. They also provide an added benefit in that they inhibit passage by larger species such as coyotes (Canis latrans) and bobcats (Lynx rufus), both of which are potential predators of kit foxes and many other species of conservation concern.

The other important conservation measure was that a suitable vegetation community was encouraged (Althouse and Meade, Inc. 2010; H. T. Harvey and Associates 2012) or allowed to grow in the arrays after construction was completed, and in some cases included active weed control efforts when necessary. Furthermore, vegetation structure on the facilities is managed, typically through sheep grazing (Fig. 3) sometimes supplemented with mechanical mowing within the arrays, and through cattle or sheep grazing on the buffer or conservation lands outside of the arrays. The goal is to keep the vegetation structure low (ideally $\leq 5 \mathrm{~cm}$ ), which is a condition favored by kit foxes (Cypher et al. 2013), their prey, and the other species of conservation concern. Vegetation management has the additional benefit of reducing combustible fuel loads within the arrays.

In addition to permeable fencing and vegetation management, a number of other conservation measures beneficial to kit foxes and the other species also were implemented.

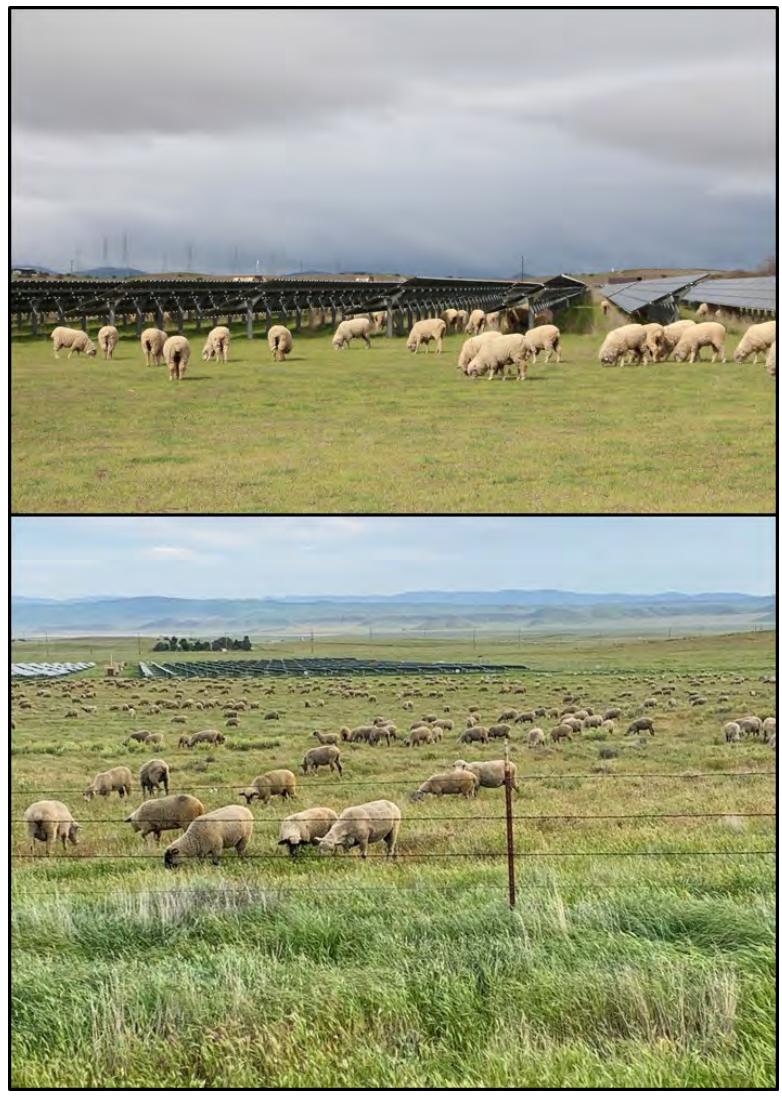

Figure 3. Sheep grazing at the Topaz Solar Farms (top - photo property of BHE Renewables and used with permission) and California Valley Solar Ranch (bottom - photo by Kristy Uschyk) in San Luis Obispo County, California. 
Animal movement corridors were incorporated into the design of all of the facilities $>500$ ha in size. Instead of constructing the solar panel arrays in a single or a few large blocks, the arrays were distributed among a larger number of smaller groupings such that habitat corridors were maintained through the project sites (Fig. 4). Available information on local animal movement patterns (e.g., pronghorn [Antilocapra americana] and elk [Cervus canadensis]) and water courses were used in determining the location of corridors. Surveys
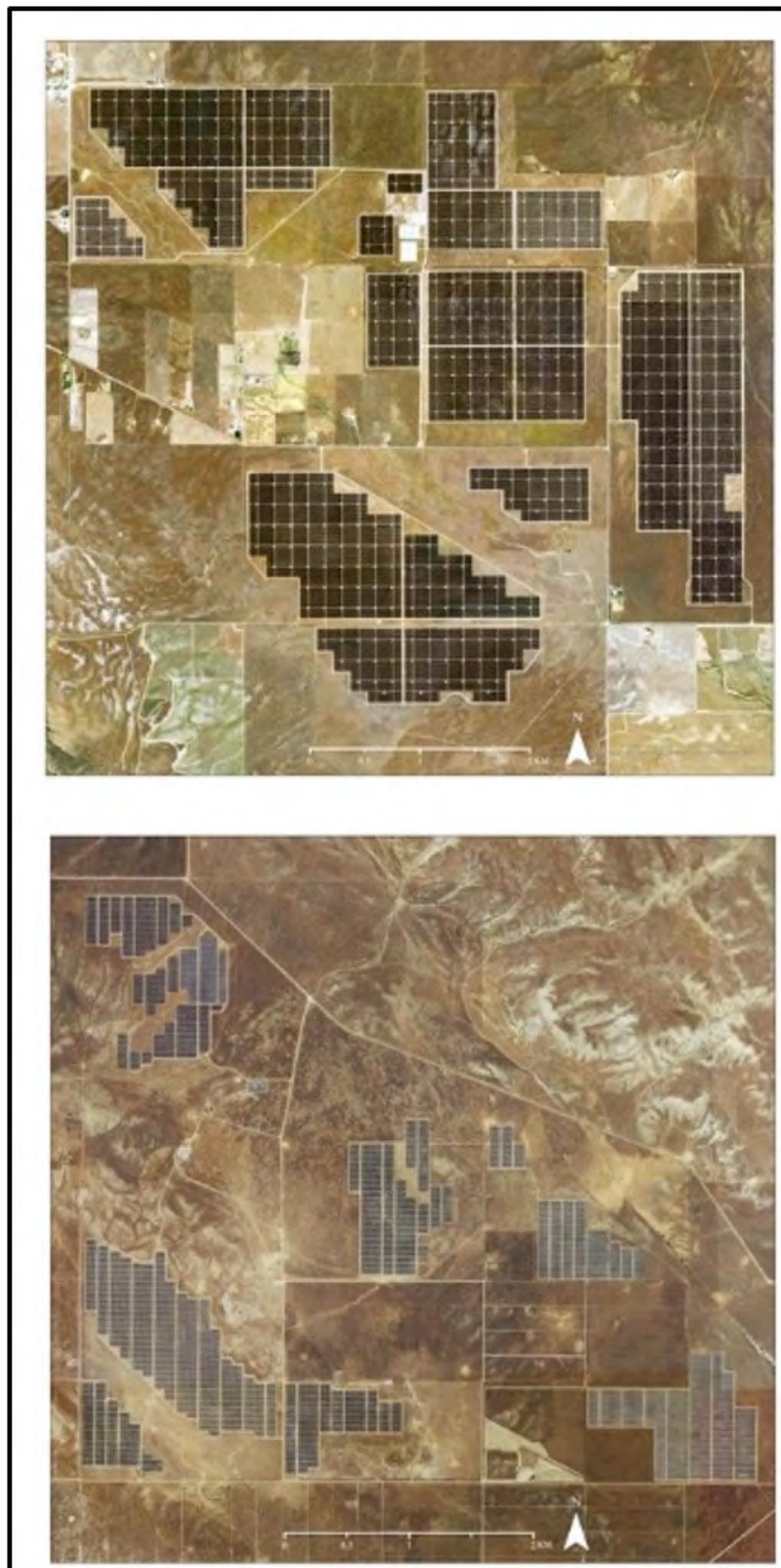

Figure 4. Google Earth images showing the wildlife movement corridors that were left open on the Topaz Solar Farms (top) and California Valley Solar Ranch (bottom) in San Luis Obispo County, California. 
are conducted for dens, burrows, and signs of species presence prior to construction and prior to conducting any ground-disturbing maintenance activities. Dens and burrows that can be avoided are left intact, even if temporarily covered, to facilitate continued use after construction or maintenance activities (an approach that has been referred to as "preserve in place"). On most of the solar sites, artificial dens were created for kit foxes and even for burrowing owls on some sites. Other measures include prohibitions on pet or feral dogs and firearms, rodenticide restrictions, and trash abatement programs. Speed limits (usually $15-25 \mathrm{~km} / \mathrm{hr}$ ) are strictly enforced and off-road driving is restricted. Hazardous substance spills are rapidly cleaned up. Another common measure is that employees, contractors, and others working outdoors at the facilities are required to complete an environmental awareness program including recognition of the species of conservation concern and required actions if a species is observed. Finally, "designated biologists" provide input on activities that potentially could cause harm to species of conservation concern and are present on-site under some circumstances to assist with implementing avoidance measures.

\section{SAN JOAQUIN KIT FOXES USING SOLAR FACILITIES}

We highlight the San Joaquin kit fox as an example of a species using photovoltaic solar facilities in the San Joaquin Desert region because (1) it has been documented using at least six of the facilities in Table 1, (2) it is a high-profile, highly charismatic species that draws lots of attention from the public and conservation groups, (3) many of the conservation measures implemented for species on the facilities were designed primarily to benefit kit foxes although other species commonly benefit from the measures as well, and (4) considerable demographic and ecological data have been collected on kit foxes using solar facilities. Kit foxes are resident on some of the larger facilities (e.g., TSF, CVSR, Panoche Valley Solar Farm [PVSF], California Flats Solar Project [CFSP] in Table 1) and use some smaller facilities to varying degrees. At the TSF, CVSR, and PVSF facilities, 3-year post-construction studies were a requirement in the Incidental Take Permits issued by the CDFW for the construction and operation of those facilities. These studies entailed quantifying demographic and ecological attributes of kit foxes on the solar facilities (i.e., "solar sites") and comparing them to attributes of foxes using nearby undeveloped control areas (i.e., "reference sites"). The TSF and CVSR studies were completed in 2017 (Cypher et al. 2019b; H. T. Harvey and Associates 2019), while the PVSF study was initiated in May 2019 and will be completed in June 2022 (Endangered Species Recovery Program [ESRP] unpublished data). A similar study was not required at the CFSP, but an opportunistic research effort on kit foxes was initiated at that facility in November 2020 (ESRP unpublished data).

Much of the demographic and ecological information presented below is from the TSF and CVSR facilities, supplemented with preliminary information from the PVSF facility. In Table 2, we compare values for various demographic and ecological attributes between solar sites and associated reference sites. To provide further perspective, in Table 3 we compare the ranges of values from the solar sites to ranges from studies on non-solar sites in kit fox population core areas where habitat conditions are most optimal (Cypher et al. 2013).

\section{Demographic Attributes}

Annual survival probabilities of adult kit foxes were not statistically different between solar and reference sites (Table 2). Indeed, on the TSF and CVSR sites, survival probabilities consistently trended higher on the solar sites compared to the reference sites (Cypher 
Table 2. Comparison of demographic and ecological values for San Joaquin kit foxes on solar sites and associated reference sites in the San Joaquin Desert region, California. Solar sites: TSF = Topaz Solar Farms (2014-17); CVSR = California Valley Solar Ranch (2014-17); PVSF = Panoche Valley Solar Farm (2019-20). See text for detailed definitions of the attributes. Data sources: TSF - Cypher et al. 2019b; CVSR - H. T. Harvey and Associates 2019; PVSF - ESRP unpublished data.

\begin{tabular}{|c|c|c|}
\hline Kit fox attribute & Solar site & Reference site \\
\hline \multicolumn{3}{|c|}{ Probability of survival } \\
\hline TSF & 0.65 & 0.49 \\
\hline CVSR & 0.76 & 0.66 \\
\hline PVSF & 0.84 & 1.0 \\
\hline \multicolumn{3}{|c|}{ Reproductive success (\%) } \\
\hline TSF & 100 & 88.9 \\
\hline CVSR & 86.7 & 86.7 \\
\hline PVSF & 100 & 100 \\
\hline \multicolumn{3}{|c|}{ Mean litter size (range) } \\
\hline TSF & $4.3(2-8)$ & $3.9(1-7)$ \\
\hline CVSR & $3.2(1-5)$ & $4.5(2-7)$ \\
\hline PVSF & $4.7(4-5)$ & $5.4(4-7)$ \\
\hline \multicolumn{3}{|c|}{ Mean mass $(\mathrm{kg})$ - Males } \\
\hline TSF & 2.48 & 2.64 \\
\hline CVSR & 2.69 & 2.53 \\
\hline PVSF & 2.72 & 2.66 \\
\hline \multicolumn{3}{|c|}{ Mean mass $(\mathrm{kg})-$ Females } \\
\hline TSF & 2.16 & 2.16 \\
\hline CVSR & 2.22 & 2.15 \\
\hline PVSF & 2.16 & 2.15 \\
\hline \multicolumn{3}{|c|}{$95 \% \mathrm{MCP}$ home range $\left(\mathrm{km}^{2}\right)$} \\
\hline TSF & 9.4 & 5.1 \\
\hline CVSR & 3.9 & 4.2 \\
\hline PVSF & 8.1 & 1.8 \\
\hline \multicolumn{3}{|c|}{ Mean dens per fox } \\
\hline TSF & 11.2 & 8.4 \\
\hline CVSR & 15.1 & 19.4 \\
\hline
\end{tabular}

et al. 2019b; H. T. Harvey and Associates 2019). The survival values from the solar sites clearly fell within the upper half of the range of values from non-solar study areas (Table 3). Lower survival values would have been expected if the solar facilities were having a detrimental effect on kit foxes. Instead, the facilities may have provided some benefits that enhanced survival. As described previously, the security fences surrounding the solar arrays inhibited entry by larger predators that commonly are the primary source of mortality for kit foxes (Cypher 2003). Furthermore, the panels also may have provided protection from 
Table 3. Comparison of demographic and ecological values for San Joaquin kit foxes on solar and non-solar sites in population core area in the San Joaquin Desert region, California. Solar sites: TSF = Topaz Solar Farms (2014-17); CVSR = California Valley Solar Ranch (2014-17); PVSF = Panoche Valley Solar Farm (2019-20). See text for detailed definitions of the attributes.

\begin{tabular}{lll}
\hline Kit fox attribute & Solar sites & Non-solar sites \\
\hline Probability of survival & $0.65-0.84$ & $0.38-1.0$ \\
Reproductive success (\%) & $86.7-100$ & $0-100$ \\
Mean litter size (range) & $3.2-4.7$ & $2.0-5.4$ \\
Litter size range & $1-8$ & $1-9$ \\
Mean mass (kg) - Males & $2.48-2.72$ & $2.33-2.66$ \\
Mean mass (kg) - Females & $2.16-2.22$ & $2.15-2.16$ \\
95\% MCP home range $\left(\mathrm{km}^{2}\right)$ & $3.9-9.4$ & $1.3-11.4$ \\
Mean dens per fox & $11.2-15.1$ & $8.4-19.4$ \\
\hline
\end{tabular}

${ }^{a}$ Data sources for solar sites: Cypher et al. 2019b, H. T. Harvey and Associates 2019, ESRP unpublished data.

${ }^{\mathrm{b}}$ Data sources for non-solar sites: Cypher et al. 2000, 2009, 2014, 2019b; ESRP unpublished data; H. T. Harvey and Associates 2019; Koopman et al. 1998; Nelson et al. 2007; Ralls and White 1995; Spiegel 1996, unpublished data; Warrick and Cypher 1999; White and Ralls 1993; Zoellick et al. 2002.

aerial predators, particularly golden eagles (Aquila chrysaetos), which can cause significant mortality (Cypher et al. 2019a,b). Thus, the arrays may have provided somewhat of a refuge effect. Finally, predators were the primary cause of mortality among kit foxes using solar facilities (with most deaths occurring outside of the fenced arrays), similar to that on the reference and other study sites (Cypher et al. 2019b; H. T. Harvey and Associates 2019). No kit fox mortalities associated with construction or operation (e.g., collision with vehicles or equipment, entombment, electrocution, etc.) of the various solar sites have been reported.

For kit foxes, a female or mated pair commonly is considered to have successfully reproduced if pups are observed at a den of the female or pair. Reproductive success did not differ between solar and reference sites (Table 2) and in most cases was identical. As with survival, reproductive success values were in the upper range of values reported from other studies (Table 3). Mean litter size also did not differ statistically between solar and reference sites (Cypher et al. 2019b; H. T. Harvey and Associates 2019; ESRP, unpublished data) and the range of litter sizes was similar as well (Table 2). The values from the solar sites were well within the range of values reported from core population areas (Table 3).

Mean mass values also did not differ statistically between solar and reference sites (Table 2; Cypher et al. 2019b; H. T. Harvey and Associates 2019; ESRP, unpublished data). Mean mass would be expected to be lower on sites if foxes were having difficulty finding enough food to maintain weight. Indeed, in comparison with results from other studies (Table 3), the mean values for males on the PVSF and females on the CVSR were the highest recorded.

\section{Ecological Attributes}

Home range size was one attribute that did differ significantly between solar and reference sites, although the pattern differed among facilities (Table 2). At the TSF and PVSP, 
mean home range size was significantly larger on the solar sites compared to the reference sites (Cypher et al. 2019b; ESRP, unpublished data). However, at CVSR, mean home range size was similar to that on the reference site (H. T. Harvey and Associates 2019). Home range size among foxes commonly is inversely related to habitat quality, particularly food availability (Macdonald 1981; Fuller and Sievert 2001; Macdonald et al. 2004). On the TSF and PVSP facilities, prey availability actually may have been lower compared to the associated reference sites (Cypher et al. 2019b; ESRP, unpublished data). The TSF was built primarily on lands that had been in active agriculture just prior to construction. Agricultural activities significantly suppressed, if not excluded, most kit fox prey. Thus, potential prey, particularly nocturnal rodents such as kangaroo rats, were in early stages of recovery on the solar site when the home range work was being conducted (Cypher et al. 2019b). The PVSP facility was constructed on lower quality habitat compared with the associated reference site where kangaroo rats occurred in much higher numbers (Center for Natural Lands Management, unpublished data). Disturbance during facility construction also may have depressed the abundance of any prey present on both the TSF and PVSP facilities. Thus, although prey likely will increase with time on both sites, lower prey abundance during the kit fox home range work likely contributed to larger home ranges on the solar sites.

The CVSR was constructed on lands that were largely intact and that supported large numbers of giant kangaroo rats. Measures were taken during construction to limit habitat impacts and avoid population concentrations. Due to high abundance, it was still necessary to relocate 225 giant kangaroo rats outside of solar facility construction areas (H. T. Harvey and Associates 2013). Giant kangaroo rats then quickly began recolonizing the array areas once construction was completed and now number in the thousands (H. T. Harvey and Associates, unpublished data). This high prey abundance, possibly along with protection from predators provided by the arrays, resulted in mean kit fox home range size being similar between the solar and reference sites (Table 2). Although kit fox home ranges trended larger on some of the solar sites, they were still within the range of mean home range sizes reported from other studies in core population areas (Table 3).

Kit foxes exhibit obligate use of subterranean dens (Grinnell et al. 1937). Kit foxes along with closely related swift foxes ( $V$. velox) are unique among North American canids in using dens daily throughout the year (Cypher 2003). Dens are used not only for rearing young, but also for diurnal resting, predator avoidance, thermoregulation, and water conservation (Koopman et al. 1998). Consequently, kit foxes annually use multiple dens, which are dispersed throughout each individual's home range. Unusually low numbers of dens used by individual foxes could indicate low den availability while unusually high numbers could indicate high levels of disturbance or even destruction of dens causing foxes to have to find new ones. However, the mean number of dens used per fox was not statistically different between solar and reference sites (Table 2). The values for the solar sites were within the range of values reported from other studies in the core population areas (Table 3).

Finally, foxes on solar sites primarily consumed heteromyid rodents, particularly kangaroo rats, and invertebrates. Food item selection by kit foxes using solar sites was similar to that on reference sites as well as that by kit foxes in other core population area study sites (Cypher et al. 2019b; H. T. Harvey and Associates 2019).

In summary, assisted by the conservation measures that were implemented, kit foxes are present and persist on several solar facilities in the San Joaquin Desert. Demographic and ecological data collected to date at three sites indicate the kit foxes are functioning in a 
manner similar to foxes on nearby reference sites (Table 1). Clearly, solar facilities of any size can be constructed and operated in a manner that is compatible with continued use by kit foxes. Furthermore, although intensive quantitative studies similar to those for kit foxes have not been conducted for other species, a number of other species of conservation concern also have been documented as resident on or at least occasionally using solar facilities (Table 1). As with kit foxes, these species undoubtedly benefit from the conservation measures implemented at the facilities, including the potential refugium effect afforded by the fenced arrays and vegetation management. Furthermore, the solar farms might even enhance regional carrying capacity when constructed on marginal habitat such as dryland agricultural lands or even many grazing lands where the common use of rodenticides and other practices can be detrimental to species. As an example, the CFSP facility was constructed in an area with suboptimal habitat for kit foxes, and foxes were present in low abundance in a limited area prior to construction. Now that construction is complete, foxes occur in greater abundance and are distributed throughout the facility (Althouse and Meade, Inc., unpublished data).

\section{SPECIES AND SOLAR FACILITIES IN OTHER REGIONS}

The findings above have implications that potentially extend beyond the San Joaquin Desert region. Numerous photovoltaic solar facilities also are being constructed in the Mojave Desert and other regions in California and throughout the western United States, and these facilities have the potential to impact other rare species (Leitner 2009; Lovich and Ennen 2011; National Renewable Energy Laboratory 2011; Cameron et al. 2012; Moore-O'Leary et al. 2017; Boroski 2019). These facilities are being constructed on thousands of hectares of habitat and the potential for further habitat impacts is considerable. In the Desert Renewable Energy Conservation Plan (DRECP) for the Mojave Desert (BLM 2016), approximately 130,000 ha within "Development Focus Areas" have been identified as being potentially suitable for solar facilities. This total just includes BLM lands and does not include other public or private lands that also might be suitable for the construction of solar facilities.

The DRECP also identifies 39 animal and plant species of conservation concern that potentially could be impacted by development of habitat in the Mojave Desert (BLM 2015). Of these 39 species, 22 are Federal or State listed as Endangered or Threatened. Current policy and practices at photovoltaic solar facilities in the Mojave typically entail actively or passively translocating species of conservation concern off facility construction sites and then using exclusionary fencing to prevent those species from returning, even once construction has been completed. Reduction or elimination of natural vegetation on sites further discourages species from returning. (For examples of typical practices currently implemented or proposed for photovoltaic solar sites in the Mojave Desert of California, see USFWS 2014; BLM 2019; ECORP Consulting, Inc. 2019; Michael Baker International 2019).

Translocation during construction can be an important avoidance and minimization strategy, but exclusion can increase local habitat loss, fragmentation, and loss of demographic and genetic connectivity. Also, survival of translocated individuals not uncommonly is low, particularly when "hard release" strategies are used in which translocated individuals are immediately liberated at the release site (e.g., Chipman et al. 2008; Germano 2010; Hamilton et al. 2010; Scrivner et al. 2016; Mengak 2018). Furthermore, residents in the areas where translocated individuals are released also could be adversely affected through increased competition (particularly if the resident population is already at carrying capacity), crowding stress, disruption of social units, and introduction of disease (e.g., Griffith and Scott 1993; 
Chipman et al. 2008; Shier and Swaisgood 2012; Mengak 2018).

The DRECP list of species that potentially could be affected by solar facilities includes a number of species that occur in the arid, sparsely vegetated, relatively flat areas (that are optimal for solar energy development) with ecological requirements that are similar to those of San Joaquin Desert species. These species include Agassiz's desert tortoise, flat-tailed horned lizard (Phrynosoma mcallii), Mojave fringe-toed lizard (Uma scoparia), burrowing owl, Mohave ground squirrel, desert kit fox (Vulpes macrotis arsipus), and a number of the plant species. These species conceivably could occupy and use solar facilities if conservation measures similar to those implemented on the San Joaquin Desert facilities (e.g., permeable fencing, vegetation management, artificial burrows, speed limits, etc.) were implemented on the Mojave Desert facilities. Other species with different ecological requirements also might be accommodated with these or alternative conservation measures.

A critical need is to identify and evaluate potential conservation strategies and specific measures that could facilitate use of photovoltaic solar facilities by species of conservation concern in the Mojave Desert and other regions. This process is likely to require some years, as it did in the San Joaquin Desert. This effort is vital to verify that species can indeed use solar facilities as well as to identify the most efficacious approaches. Any such effort obviously would be facilitated by a collaborative relationship between solar developers and natural resource agencies. Indeed, such an effort is in progress near Pahrump, Nevada. In collaboration with the U.S. Fish and Wildlife Service and the University of Nevada, the Valley Electric Association (VEA) teamed with Bombard Renewable Energy to construct a 32-ha wildlife-friendly demonstration facility called the Community Solar Project (VEA 2020). Conservation measures implemented at this facility included minimizing vegetation disturbance during construction, planting native shrub seedlings, seeding some areas with a native seed mix, and installing $25 \times 18-\mathrm{cm}$ openings at $80-\mathrm{m}$ intervals along the base of the security fence. Extensive monitoring is being conducted and desert tortoises (as well as desert kit foxes, rattlesnakes, rabbits, and other species) are commonly passing through the fence and the using the habitat on the facility. Plants favorable to desert tortoises and other wildlife appear to be thriving in the microclimate created by the solar panels (VEA 2020).

The U.S. Fish and Wildlife Service and California Department of Fish and Game have statutory requirements related to take that must be met. The California Endangered Species Act requires that "take must be minimized and fully mitigated" (Fish \& G. Code §2081(b); Cal. Code Regs., tit. 14, §§783.2-783.8) and the federal Endangered Species Act requires that "the applicant must to the maximum extent practicable, minimize and mitigate the impacts of take" (50 C.F.R. $\$ 17.22(b)(2))$. To fulfill these requirements, solar facility developers commonly purchase off-site conservation lands to mitigate the impacts of their facilities to species of conservation concern and also provide funds for the long-term management of these lands. These costs are substantial. This understandably reduces enthusiasm for also incurring the additional costs of implementing on-site conservation measures, the cost for which also could be substantial over a 30 -year facility operational period.

Another concern is that if species inhabit or occasionally use solar facilities, there is a risk of accidental injury or death from operations and maintenance activities. With the implementation of appropriate conservation measures this risk would be low, and if the conservation measures were designed to enhance reproduction and survival, then this could easily compensate for incidental losses. Indeed, to date, mortalities of individuals of species of conservation concern on the San Joaquin Desert solar facilities have been ex- 
tremely rare. Furthermore, even a low number of occasional mortalities would still result in larger overall populations of species. For example, if solar facilities could support 1,000 individuals of a species, translocation and exclusion could result in the loss of a proportion of those individuals, given the lower survival of translocated individuals and adverse effects on residents in release sites, as discussed previously. However, if the species was allowed to continue to occupy the solar facility and even if $5 \%$ of the individuals died annually due to maintenance and operation activities (given the results from the San Joaquin Desert facilities, a 5\% annual rate would be rather high and therefore unlikely), that would still leave 950 individuals, which likely is a higher survival rate than would be realized if the 1,000 individuals were translocated. Also, continued occupation of the facilities would reduce habitat fragmentation effects and help maintain connectivity.

Identifying conservation approaches that benefit species of conservation concern on photovoltaic solar facilities, meet regulatory requirements, and are cost effective will be challenging. This will require some time and testing, and efforts will benefit from collaboration between solar developers, natural resource agencies, researchers, and others. We only address photovoltaic facilities, but similar conservation measures may be possible at other types of facilities as well (e.g., power tower, solar thermal). The successes realized in the San Joaquin Desert as well as early results from the VEA demonstration facility in the Mojave Desert suggest that the conservation outcomes can be worth the investment. These efforts should be built upon, improved, and then widely implemented so that we can have renewable electricity and our species, too.

\section{ACKNOWLEDGMENTS}

Numerous individuals over many years contributed information that led to the conception and preparation of this paper. We greatly appreciate their contributions.

\section{LITERATURE CITED}

Althouse and Meade, Inc. 2010. Topaz Solar Farms San Joaquin kit fox mitigation and monitoring plan. Althouse and Meade, Inc., Paso Robles, CA, USA.

Boroski, B. B. 2019. Solar energy: a technology with multi-scale opportunities to integrate wildlife conservation. Pages 177-197 in C. E. Moorman, S. M. Grodsky, and S. P. Rupp, editors. Renewable Energy and Wildlife Conservation. Johns Hopkins University Press, Baltimore, MD, USA.

Butterfield, H. S., D. Cameron, E. Brand, M. Webb, E. Forsburg, M. Kramer, E. O’Donoghue, and L. Crane. 2013. Western San Joaquin Valley least conflict solar assessment. The Nature Conservancy, San Francisco, CA, USA.

California Department of Fish and Wildlife (CDFW). 2020. Species of Special Concern. Available from: https://wildlife.ca.gov/Conservation/SSC

California Energy Commission. 2020. California Solar Energy Statistics and Data. Available from: https://ww2.energy.ca.gov/almanac/renewables_data/solar/index_cms. php

Cameron, D. R., B. S. Cohen, and S. A. Morrison. 2012. An approach to enhance the conservation-compatibility of solar energy development. PLoS ONE 7(6):e38437.

Chipman, R., D. Slate, C. Rupprecht, and M. Mendoza. 2008. Downside risk of wildlife translocation. Pages 223-232 in B. Dodet, A. R. Fooks, T. Muller, N. 
Tordo N, and the Scientific and Technical Department of the OlE, editors. Towards the Elimination of Rabies in Eurasia. Developmental Biology Basel, Karger. Available from: https://digitalcommons.unl.edu/cgi/viewcontent. cgi? article $=2895 \&$ context $=$ icwdm_usdanwrc.

Cypher, B. L. 2003. Foxes. Pages 511-546 in G. A. Feldhamer, B. C. Thompson, and J. A. Chapman, editors. Wild Mammals of North America: Biology, Management, and Conservation. 2nd edition. Johns Hopkins University Press, Baltimore, MD, USA.

Cypher, B. L., C. D. Bjurlin, and J. L. Nelson. 2009. Effects of roads on endangered San Joaquin kit foxes. Journal of Wildlife Management 73:885-893.

Cypher, B. L., C. M. Fiehler, T. L. Westall, C. L. Van Horn Job, and E. C. Kelly. 2014. San Joaquin kit fox conservation in the northern Carrizo Plain: baseline demographic and ecological attributes. California State University-Stanislaus, Endangered Species Recovery Program, Turlock, CA, USA.

Cypher, B. L., S. E. Phillips, and P. A. Kelly. 2013. Quantity and distribution of suitable habitat for endangered San Joaquin kit foxes: conservation implications. Canid Biology and Conservation 16:25-31.

Cypher, B. L., K. A. Spencer, T. L. Westall, and D. E. Meade. 2019a. Golden eagle predation on endangered San Joaquin kit foxes. Western North American Naturalist 79:556-563.

Cypher, B. L., G. D. Warrick, M. R. M. Otten, T. P. O’Farrell, W. H. Berry, C. E. Harris, T. T. Kato, P. M. McCue, J. H. Scrivner, and B. W. Zoellick. 2000. Population dynamics of San Joaquin kit foxes at the Naval Petroleum Reserves in California. Wildlife Monographs 145.

Cypher, B. L., T. L. Westall, K. A. Spencer, D. E. Meade, E. C. Kelly, J. Dart, and C. L. Van Horn Job. 2019b. Response of San Joaquin kit foxes to Topaz Solar Farms: implications for conservation of kit foxes. California State University-Stanislaus, Endangered Species Recovery Program, Turlock, CA, USA.

de León, K. 2018. Senate Bill 100: California Renewables Portfolio Standard Program: Emissions of Greenhouse Gases, Chapter 312, Statutes of 2018. Available from: https://leginfo.legislature.ca.gov/faces/billTextClient.xhtml?bill_ id $=201720180$ SB 100

ECORP Consulting, Inc. 2019. Biological impact analysis and mitigation report for the High Desert Solar Project: based on 2018 Comprehensive Biological Technical Report. San Bernardino County, CA, USA. Available from: https://www.victorvilleca.gov/home/showpublisheddocument?id $=2748$

Fuller, T. K., and P. R. Sievert. 2001. Carnivore demography and the consequences of changes in prey availability. Pages $163-178$ in J. L. Gittleman, S. M. Funk, D. Macdonald, and R. K. Wayne, editors. Carnivore Conservation. Cambridge University Press, Cambridge, UK.

Germano, D. J. 2010. Survivorship of translocated kangaroo rats in the San Joaquin Valley, California. California Fish and Game 96:82-89.

Germano, D. J., G. B. Rathbun, L. R. Saslaw, B. L. Cypher, E. A. Cypher, and L. M. Vredenburgh. 2011. The San Joaquin desert of California: ecologically misunderstood and overlooked. Natural Areas Journal 31:138-147.

Griffith, B., and J. M. Scott. 1993. Animal translocation and potential disease transmission. 
Journal of Zoo and Wildlife Medicine 24:2231-2236.

Grinnell, J., D. S. Dixon, and J. M. Linsdale. 1937. Fur-bearing Mammals of California. Volume 2. University of California Press, Berkeley, CA, USA.

H. T. Harvey and Associates. 2012. California Valley Solar Ranch Project San Luis Obispo County, California Habitat Restoration and Revegetation Plan with Addendum. H.T. Harvey and Associates, Fresno, CA, USA.

H. T. Harvey and Associates. 2013. California Valley Solar Ranch Project giant kangaroo rat (Dipodomys ingens) relocation final report. H.T. Harvey and Associates, San Luis Obispo, CA, USA.

H. T. Harvey and Associates. 2019. California Valley Solar Ranch San Joaquin kit fox monitoring study: final report. H.T. Harvey and Associates, San Luis Obispo, CA, USA.

Hamilton, L. P., P. A. Kelly, D. F. Williams, D. A. Kelt, and H. U. Wittmer. 2010. Factors associated with survival of reintroduced riparian brush rabbits in California. Biological Conservation 143:999-1007.

Hernandez, R. R., S. B. Easter, M. L. Murphy-Mariscal, F. T. Maestre, M. Tavassoli, E. B. Allen, C. W. Barrows, J. Belnap, R. Ochoa-Hueso, S. Ravi, and M. F. Allen. 2014. Environmental impacts of utility-scale solar energy. Renewable Sustainable Energy Reviews 29:766-779.

Hoffacker, M. K., M. F. Allen, and R. R. Hernandez. 2017. Land-sparing opportunities for solar energy development in agricultural landscapes: a case study of the Great Central Valley, CA, United States. Environmental Science and Technology 51:14472-14482.

Kern County Planning Department. 2020. List of approved/proposed projects for Kern County. Available from: https://psbweb.co.kern.ca.us/planning/pdfs/renewable/ MasterKernSolarProjectsList.pdf

Koopman, M. E., J. H. Scrivner, J., and T. T. Kato. 1998. Patterns of den use by San Joaquin kit foxes. Journal of Wildlife Management 62:373-379.

Leitner, P. 2009. The promise and peril of solar power. The Wildlife Professional 3:48-53.

Lovich, J. E., and J. R. Ennen. 2011. Wildlife conservation and solar energy development in the desert southwest, United States. BioScience 61:982-992.

Macdonald, D. W. 1981. the social organization of the red fox (Vulpes vulpes). Pages 918949 in J. A. Chapman and D. Pursley, editors. Proceedings of the Worldwide Furbearer Conference, Frostburg, MD, USA.

Macdonald, D. W., S. Creel, and M. G. Mills. 2004. Canid society. Pages 85-106 in D. W. Macdonald and C. Sillero-Zubiri, editors. The Biology and Conservation of Wild Canids. Oxford University Press, Oxford, UK.

Mengak, M. T. 2018. Wildlife Translocation. Wildlife Damage Management Technical Series. USDA, APHIS, Wildlife Services National Wildlife Research Center. Fort Collins, CO, USA.

Michael Baker International. 2019. Daggett Solar Power Facility, Final Environmental Impact Report. Available from: http://www.sbcounty.gov/uploads/LUS/Environmental/Daggett\%20Solar\%20Power\%20Facility_Final\%20EIR\%2009-04$2019 \% 20(1) \cdot p d f$

Moore, K. A., and B. M. Pavlik. 2016. Measuring and evaluating rare desert plant demography in the California deserts: implications for solar energy development. 
California Energy Commission, Sacramento, CA, USA.

Moore-O'Leary, K. A., R. R. Hernandez, D. S. Johnston, S. R. Abella, K. E. Tanner, A. C. Swanson, J. Kreitler, and J. E. Lovich. 2017. Sustainability of utility-scale solar energy -critical ecological concepts. Frontiers in Ecology and the Environment 15:385-394.

National Renewable Energy Laboratory. 2011. Dynamic maps, GIS data and analysis tools: Solar maps. Available from: www.nrel.gov/gis/solar.html

Nelson, J. L., B. L. Cypher, C. D. Bjurlin, and S. Creel. 2007. Effects of habitat on competition between kit foxes and coyotes. Journal of Wildlife Management 71:14671475.

Pearce, D., J. Strittholt, T. Watt, and E.N. Elkind. 2016. A path forward: identifying leastconflict solar PV development in California's San Joaquin Valley. Conservation Biology Institute, Corvallis, OR, USA.

Phillips, S. E., and B. L. Cypher. 2019. Solar energy development and endangered species in the San Joaquin Valley, CA: identification of conflict zones. Western Wildlife 6:29-44.

Ralls, K., and P. J. White. 1995. Predation on San Joaquin kit foxes by larger canids. Journal of Mammalogy 76:723-729.

REN21. 2016. Renewables 2016 global status report. Available from: www.ren21.net/wpcontent/uploads/2016/05/GSR_2016_Full_Report_lowres.pdf

Scrivner, J. H., T. P. O'Farrell, K. Hammer, and B. L. Cypher. 2016. Translocation of the endangered San Joaquin kit fox, Vulpes macrotis mutica: a retrospective assessment. Western North American Naturalist 76:90-100.

Shier, D. M., and R. R. Swaisgood. 2012. Fitness costs of neighborhood disruption in translocations of a solitary mammal. Conservation Biology 26:116-123.

Solar Energy Industries Association. 2016. Solar industry research data. Available from: www.seia.org/research-resources/solar-industry-data

Spiegel, L. K. 1996. Studies of the San Joaquin kit fox in undeveloped and oil-developed areas. California Energy Commission, Sacramento, CA, USA.

Stoms, D. M., S. L. Dashiell, and F. W. Davis. 2013. Siting solar energy development to minimize biological impacts. Renewable Energy 57:289-98.

Tsoutsos, T., N. Frantzeskaki, and V. Gekas. 2005. Environmental impacts from solar energy technologies. Energy Policy 33: 289-296.

U.S. Bureau of Land Management (BLM). 2015. Desert Renewable Energy Conservation Plan, Proposed Land Use Plan Amendment and Final Environmental Impact Statement, Chapter III.7 - Biological Resources. Available from: https://eplanning.blm.gov/public_projects/lup/66459/20012405/250016906/III.07_Biological_Resources.pdf

U.S. Bureau of Land Management (BLM). 2016. Desert Renewable Energy Conservation Plan, Land use plan amendment. Available from: https://eplanning.blm.gov/public_projects/lup/66459/133474/163144/DRECP_BLM_LUPA.pdf

U.S. Bureau of Land Management (BLM). 2019. Desert Quartzite Solar Project, Final Plan Amendment, Environmental Impact Statement/Environmental Impact Report. Available from: https://planning.rctlma.org/Portals/14/Postings/Desert \%20 Quartzite\%20Solar\%20Project/FinalEIR/Desert\%20Quartzite\%20Final\%20EISEIR.pdf 
U.S. Fish and Wildlife Service (USFWS). 1998. Recovery plan for upland species of the San Joaquin Valley, California. United States Fish and Wildlife Service, Portland, OR, USA.

U.S. Fish and Wildlife Service (USFWS). 2014. RE Cinco Solar Facility Project, Habitat Conservation Plan, Draft Environmental Assessment. U.S. Fish and Wildlife Service, Palm Springs, CA, USA. Available from: https://www.fws.gov/ventu$\mathrm{ra} / \mathrm{docs} / \mathrm{hcps} / \mathrm{draft} / \mathrm{cinco}-$ solar/2014-10-03\%20Cinco $\% 20$ USFWS $\% 20 \mathrm{EA} \% 20$ LTE\%20508\%20compliant.pdf

Valley Electric Association (VEA). 2020. Websites with information on the wildlifefriendly VEA Community Solar Project. Available from: https://vea.coop/projects/community-solar-project

Warrick, G. D., and B. L. Cypher. 1999. Variation in body mass of San Joaquin kit foxes. Journal of Mammalogy 80:972-979.

White, P. J., and K. Ralls. 1993. Reproduction and spacing patterns of kit foxes relative to changing prey availability. Journal of Wildlife Management 57:861-867.

Zoellick, B. W., C. E. Harris, B. T. Kelly, T. P. O’Farrell, T. T. Kato, and M. E. Koopman. 2002. Movements and home ranges of San Joaquin kit foxes relative to oil-field development. Western North American Naturalist 62:151-159.

Submitted 7 January 2021

Accepted 16 April 2021

Associate Editor was J. Rudd 